\title{
LATE JURASSIC OF THE RUSSIAN PLATFORM: AMMONITE EVOLUTION AND PALEOENVIRONMENTS
}

\author{
Mitta V. V. ${ }^{1}$, and Bogomolov Yu. I. ${ }^{2}$ \\ ${ }^{1}$ Paleontological Institute of the Russian Academy of Sciences, mitta@paleo.ru \\ ${ }^{2}$ Interregional Social Association of Paleontologists and Mineralogists, iljich@dubki.ru
}

\begin{abstract}
During the terminal age of Late Jurassic a considerable decrease in ammonoid taxonomic diversity and distinct changes of ammonite shell morphotypes are recorded in the Central Russian Basin. By the end-Volgian, ammonites are represented by only two genera belonging to a single family, which differ markedly in their shell form. The end-Jurassic decrease in ammonoid biodiversity started in the mid-Volgian and is correlated first of all with shallowing of the sea.
\end{abstract}

Key words: Volgian, Ryazanian, ammonites, biodiversity.

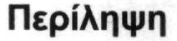

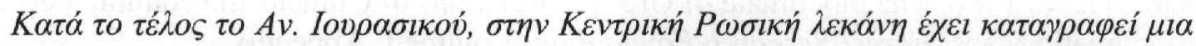

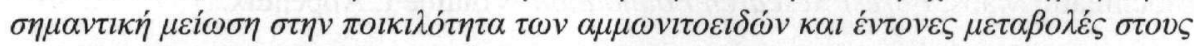

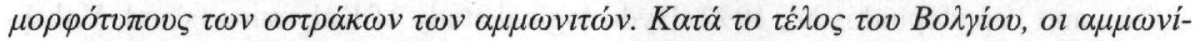

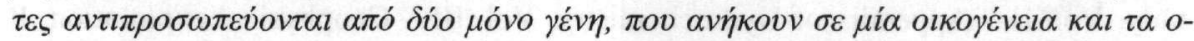

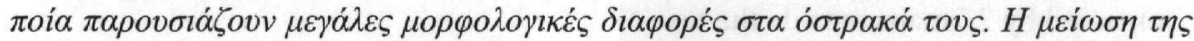

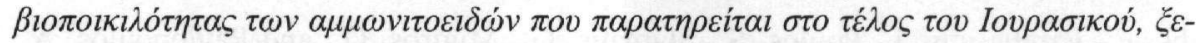

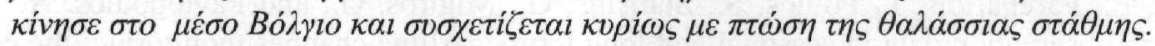

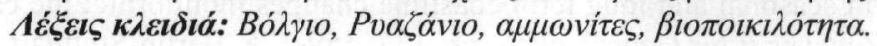

\section{Introduction}

The end of Jurassic was marked with global paleogeographic transformations. Sedimentary settings and environments for marine life changed essentially, greatly affecting the ammonoid evolution.

In this contribution the peculiarities in evolution of Late Jurassic ammonites on the territory of Russian Platform are considered. Such features as position of this basin at the junction of Boreal and Submediterranean Provinces, its frequent isolation from northern/eastern and southern/western basins, and simultaneously not infrequent faunal invasions from these basins during comparatively short time intervals, have a great potential for global Boreal-Tethyan correlations, as well as for the study of faunal evolution in an epoch of constant changes.

\section{Material}

The research of ammonites from the Upper Jurassic of Russian platform was initiated by one of the authors in 1980. Since then, extensive materials from various localities, mainly from the Mos- 
cow, Yaroslavl, Kostroma, Ulyanovsk, Samara and Ryazan regions of the Central Russia have been collected. Study of these collections totaling more than 15000 specimens allowed correcting the taxonomic position and stratigraphical distribution for many Late Jurassic ammonoid taxa, first of all Perisphinctoidea from the Volgian Stage (Mitta 1993, etc.). Below changes in the form of ammonite conchs in the Central Russian basin at the end of the Jurassic, and possible connection of these changes with abiotic events are discussed.

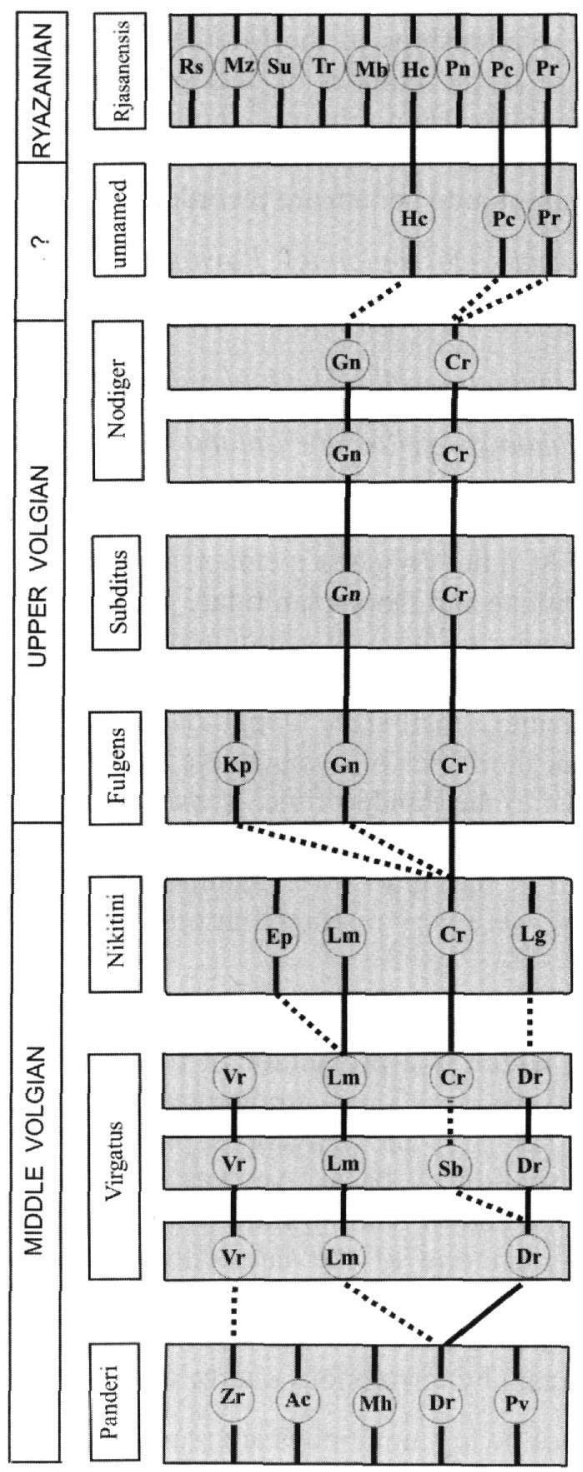
Ac Acuticostites
Cs Caseyceras
Cr Craspedites
Dr Dorsoplanites
Ep Epivirgatites
Gn Garniericeras
He Hectoroceras
Kp Kachpurites
Lg Laugeites
Lm Lomonossovella
Mb Malbosiceras
Mz Mazenoticeras
Mh Michalskia
Pv Pavlovia
Pr Praesurites
Pn Pronjaites
Pc Pseudocraspedites
Rs Riasanites
Sb Serbarinovella
Su Subalpinites
Tr Transcaspiites
Vr Virgatites
Zr Zaraiskites

Figure 1 - Succession of ammonite genera on the Russian Platform and their phylogenetic relationships from the Panderi Zone, Middle Volgian up to the Rjasanensis Zone, Ryazanian (after Mitta 2004, modified)

\section{Results and Discussion}

First endemic ammonoid faunas appear in the Central Russian Basin already in the latest Kimmeridgian - earliest Early Volgian. However, these ammonites still do not differ markedly from their precursors occurring almost everywhere in the Northern Hemisphere, having mainly Tethyan 
roots and being diverse in the types of coiling of conchs (further referred as "shell morphotypes"). The most significant event at this time-interval is the final disappearance of Cardioceratidae, a large family that appeared already in the Bajocian in the boreal regions and was distributed subglobally in Jurassic seas by the end of the Middle Jurassic. Note that sediments of that time on the Russian Platform are represented by dark calcareous clays similar to the classical Kimmeridge Clay of Dorset.

In the Fig. 1 the succession and phylogenetic relationships of the Middle and Late Volgian ammonitids is shown, illustrating gradual decrease in the number of taxa of generic rank. For the Early Volgian the generic composition of ammonites has not been determined finally yet, but the number of genera in each chronozone is similar to that in the earliest Middle Volgian. In the Middle Volgian of Russian Platform the following ammonite genera are recorded:

Panderi Zone: Zaraiskites, Acuticostites, Michalskia, Dorsoplanites, Pavlovia;

Virgatus Zone, Gerassimovi Subzone: Virgatites, Lomonossovella, Dorsoplanites;

Virgatus Zone, Virgatus Subzone: Virgatites, Lomonossovella, Dorsoplanites, Serbarinovella;

Virgatus Zone, Ivanovi Subzone: Virgatites, Lomonossovella, Dorsoplanites, Craspedites;

Nikitini Zone: Epivirgatites, Lomonossovella, Laugeites, Craspedites.

During the whole Early Volgian (and part of Middle Volgian) members of two relatively small boreal families of perisphinctoid origin, Virgatitidae and Dorsoplanitidae, predominate in the Central Russian Sea. Shells of these ammonites belong to the well sculptured discocone morphotype (Plate 1, Figs 6, 7), determining their ecotype as nectobenthos (Besnosov and Mitta 2002). Apparently by the earliest Middle Volgian (Panderi Zone), small-sized Oppeliidae with discoconic shells finally disappear. Note that wide distribution of the facies of combustible shales and bithuminous clays over the Russian Platform is confined just to the Panderi time. It was the most global distribution of anoxic environments over this territory in the Late Jurassic; the preceding ones, at the boundary of Middle and Upper Oxfordian and in the mid-Lower Kimmeridgian, and the subsequent one, at the Jurassic/Cretaceous boundary, were very restricted in time and space (Baudin et al. 1996, Hantzpergue et al. 1998).

Already in the next chron (Virgatus) of the Middle Volgian, an essentially new taxon separates from Dorsoplanitidae, the genus Craspedites, which is a progenitor of the family Craspeditidae and the following (entirely Cretaceous) Polyptychitidae. These ammonites, at first identifiable as small-sized poorly sculptured oxycones (Plate 1, Fig. 5) and platycones, probably turned out to be best adapted for sublittoral conditions in the shallowing basin. Anyway, at the end of Virgatus time the last Virgatitidae went extinct, and at the end of Nikitini time Dorsoplanitidae also disappeared from the Central Russian Sea. Note that one of the latest dorsoplanitids, the genus Laugeites, has the platyconic shell with poorly developed sculpture. The deposits of latest Middle Volgian are represented usually by shallow-water glauconitic sands and sandstones, often with phosphorite interlayers, rarely (in near-shore areas) by ferruginous quartz sand.

In the Upper Volgian of Russian Platform the following ammonites are recorded:

Fulgens Zone: Kachpurites, Craspedites, Garniericeras;

Subditus Zone: Craspedites, Garniericeras;

Nodiger Zone: Craspedites, Garniericeras. 


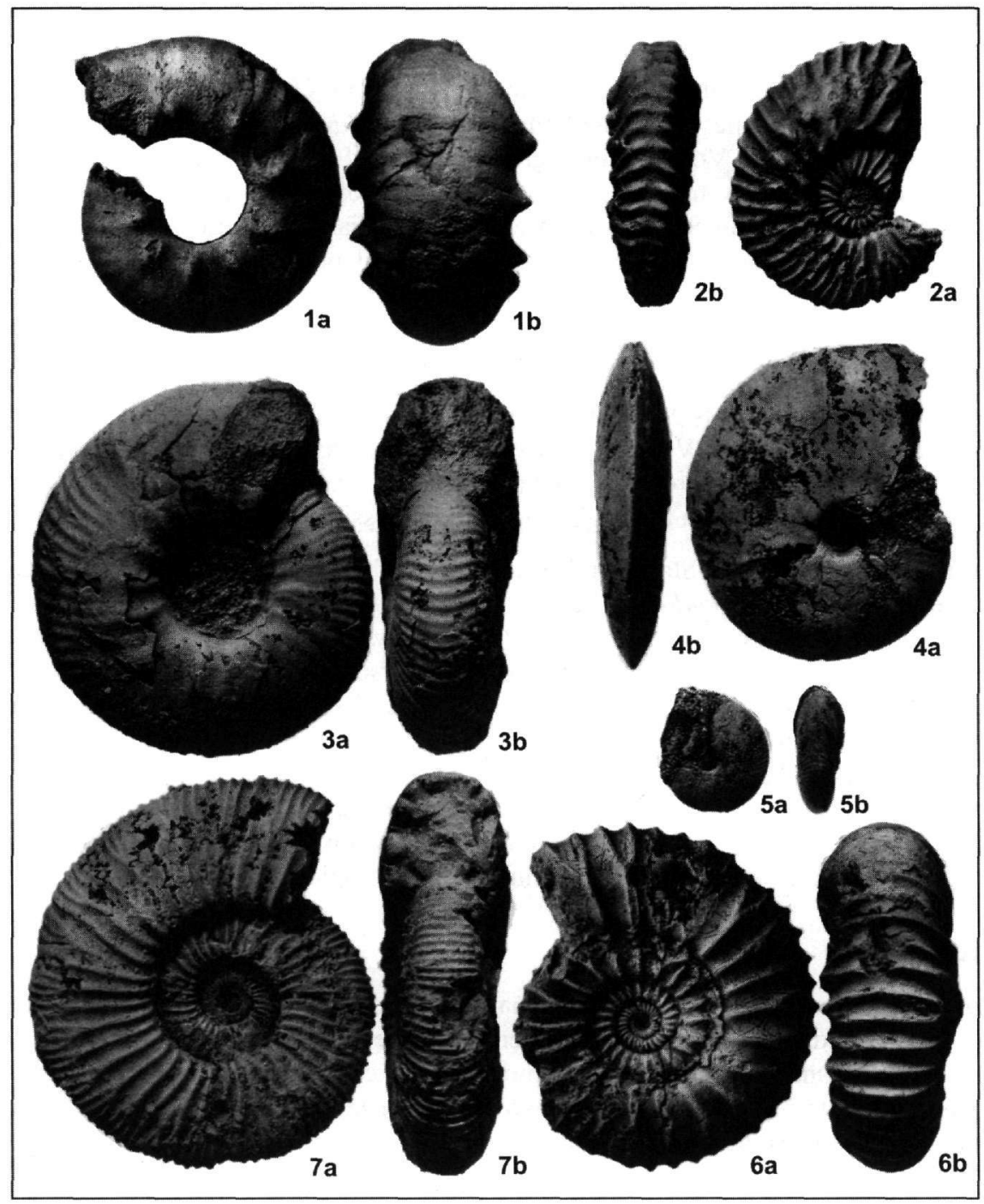

Plate 1 - Ammonoid morphotypes from the Russian Platform in the latest Jurassic-earliest

Cretaceous. 1. Laticone with spine-like lateral tubercles (Craspedites milkovensis

(Stremooukhov), Vernadsky Geological Museum, Moscow, No VI-36/1; Moscow, Upper

Volgian Nodiger Zone). 2. Discocone well sculptured (Mazenoticeras sp., Paleontological Institute, Moscow, No 3990/272; Moscow region, Ryazanian Rjasanensis Zone). 3. Platycone poorly sculptured (Craspedites subditus (Trautschold), Paleontological Institute, Moscow, No 3990/269, Moscow region, Upper Volgian Subditus Zone). 4. Oxycone with undulate ribs (Garniericeras catenulatum (Fischer v. Waldheim), Paleontological Institute, Moscow, No 3990/268; Moscow region, Upper Volgian Subditus Zone). 5. Oxycone poorly sculptured (Craspedites ivanovi Gerasimov, Paleontological Institute, Moscow, No 3990/271, Yaroslavl region, Middle Volgian Virgatus Zone). 6. Discocone well sculptured (Pavlovia pavlowi (Michalsky), Museum of All-Russian Geological Institute, S.-Petersbourg, No 197/300;

Moscow, Middle Volgian Panderi Zone). 7. Discocone moderately sculptured (Ilowaiskya schaschkovae Ilovaisky), Paleontological Institute, Moscow, No 3990/270; Chuvashiya, Lower Volgian Pseudoscythica Zone) 
Respectively, in the Late Volgian the Central Russian ammonites are represented exclusively by the family Craspeditidae, showing the shell morphotypes clearly differing from most of preceding perisphinctoids: these are smooth or poorly sculptured platycones (Craspedites, Kachpurites; Plate 1, Fig. 3) and classical oxycones with undulating sculpture (Garniericeras; Plate 1, Fig. 4). By the mid-Nodiger time of the Late Volgian, the regression reached its maximum. In the second half of that time (Milkovensis) a new transgression started (Rosanov 1909), reaching its apogee at the Rjasanensis time of Ryazanian Stage (equivalent to Berriasian Stage, Lower Cretaceous), when through the straits that opened from southwest, north and northeast numerous immigrants of Tethyan and Boreal origin reached the Central Russian Basin. The terminal zone of the Jurassic, as well as the basal zone of the Cretaceous, is usually represented on the Russian Platform by glauconitic sandstones and sands with phosphorites, rarely by near-shore quartz sands.

Events at the Jurassic/Cretaceous boundary merit special attention. Here we only note, that on the shell of the last craspedite of the Volgian, Craspedites milkovensis, in contrast to all its congeners, the spine-like lateral outgrowths are developed (Plate 1, Fig. 1). Is it correlated with environmental changes, or mere coincidence with the beginning of transgression? No answer at present.

In the lower zone of Ryazanian Stage (and of the whole Cretaceous), besides the descendants of Craspeditidae (Praesurites, Pseudocraspedites, Hectoroceras, Pronjaites), immigrants from the west belonging to the family Neocomitidae (Riasanites, Mazenoticeras, Subalpinites, Transcaspiites, Malbosiceras) are present. Note that of all diverse shell morphotypes in Berriasian ammonoids of Rjasanensis Zone, exactly the well sculptured discocones (Plate 1, Fig. 2) and platycones with one, two or even three rows of tubercles often developed into spine-like outgrowths, prevail in immigrants of Tethyan origin. At the same time, the ammonites of Boreal origin in this zone (partly having local roots) show diverse shell morphotypes: poorly and well sculptured platycones and discocones, poorly sculptured oxycones and sub-oxycones. Such diversity is an evidence of deepening of the basin with growing number of ecological niches.

\section{Conclusions}

Analysis of the data on ammonoid diversity dynamics during the terminal age of the Late Jurassic shows, that by the end of this period a considerable decrease in the number of taxa is recorded (Late Volgian crisis), and the ammonite shell morphotypes change noticeably. By the end-Volgian time, the ammonites are represented by only two genera, differing markedly in the shell form. The end-Jurassic decrease in ammonoid biodiversity started in the mid-Volgian and is most probably correlated with changes of hydrodynamic regime (or simply regression) (first of all, shallowing of the sea) and possibly cooling.

\section{Acknowledgments}

We are grateful to M. Zaton and anonymous referee for helpful comments. The study is supported by Program of the Presidium of the Russian Academy of Sciences "Origin and Evolution of the Biosphere", project "Coevolutionary processes in the Marine Pelagic Biota and Its Response to the Abiotic Changes in the Critical Epochs of the Paleozoic and Mesozoic", and it is a contribution to the IGCP No 506 .

\section{References}

Baudin, F., Hantzpergue, P., Mitta, V., Olferiev, A., and Zakharov, V., 1996. Biostratigraphic correlations and black shale deposition of the Upper Jurassic from the Russian Platform, $A b$ stracts of Peri-Tethys programme, Annual meeting, Amsterdam, June, 7, 10-11pp.

Besnosov, N.V., and Mitta, V.V., 2002. Living forms and type of burial of the Late Bajocian Middle Bathonian ammonoids in North Caucasus and Central Asia, Bull. Soc. Natur. Moscow, 77(5), 49-58. (in Russian) 
Hantzpergue, P., Baudin, F., Mitta, V., Olferiev, A., and Zakharov, V., 1998. The Upper Jurassic of the Volga basin: ammonite biostratigraphy and occurrence of organic-carbon rich facies. Correlations between boreal-subboreal and submediterranean provinces. In CrasquinSoleau and É. Barrier (eds), Peri-tethys Memoir 4. Epicratonic basins of Peri-Tethyan platforms, Mém. Mus. natn. Hist. nat., 179, 9-33.

Mitta, V.V., 1993. Ammonites and zonal stratigraphy of the Middle Volgian deposits of Central Russia. Kiew, Geoprognoz, 132pp.

Mitta, V.V., 2004. On the ammonite succession in the Jurassic-Cretaceous boundary beds of the Moscow syneclise, Palaeontol. Zhurnal, 5, 17-24. In Russian; English translation: Palaeontol. Journ., 38(3), 483-491.

Rosanov, A.N., 1909. Sur la répartition de la zone à Cr. nodiger dans les environs de Moscou, $\mathrm{An-}$ nuaire géol. et minéral. de la Russie, 11(1-3), 25-41. 